\title{
Virulence, bacterocin genes and antibacterial susceptibility in Enterococcus faecalis strains isolated from water wells for human consumption
}

\author{
Carlos Padilla* and Olga Lobos
}

\begin{abstract}
The objectives of this study were to detect genes for virulence and bacteriocins in addition to studying the antimicrobial susceptibility of 78 strains of $E$. faecalis isolated from water wells for human consumption. The virulence and bacteriocin genes of 78 E. faecalis were amplified by PCR and visualized in agarose gels. The antimicrobial susceptibility was determined through diffusion agar tests and the MIC through microdilution. It was observed that the major percentage of virulence genes in the E. faecalis strains corresponds to aggA (93.5\%). The bacteriocin gene entA (64.1\%) is the most frequently detected. The studied strains exhibited different virulence and bacteriocin genes, and an important antibacterial resistance. The most common resistant phenotype $(n=14)$ corresponds to tetracycline and chloramphenicol and the less frequent $(n=2)$ to ciprofloxacin and moxifloxacin. Eight different genetic profiles were observed for virulence y bacteriocin genes. It was determined a statistical association between the bacterial resistance and some of the genetic profiles detected.
\end{abstract}

Keywords: E. faecalis, Wells, Water, Bacteriocin, Virulence, Antimicrobials

\section{Introduction}

Representants of the genus Enterococcus are part of the normal human gut microbiota, some animals, and birds. The Enterococcus out of the organism can survive in different temperature ranges, salinity, $\mathrm{pH}$ and resist some detergents as dodecyl-sodium sulfate and bile (Shepard and Gilmore 2000). Phylogenetically the enterococci are divided into 7 clusters resulting finally in 33 species (Naser et al. 2005; Köhler 2007). In human infections, $E$. faecalis and E. faecium are the most prevailing species (>90\%). The first is the most commonly isolated, but recently E. faecium has exhibited an important increase as infectious agent (Treitman et al. 2005). The enterococcal infection includes surgical wounds, endocarditis, hepatobiliary sepsis, urinary tract infections, bacteremias and neonatal sepsis among the most important (Poh et al. 2006). The majority of the enterococcal infections are endogeneous, but the crossed infection occurs mainly in hospitalized patients (Cookson et al. 2006). Enterococcus in USA is the fourth most common cause of nosocomial

\footnotetext{
* Correspondence: cpadilla@utalca.cl

Departamento de Microbiología, Universidad de Talca, Talca Camino Lircay s/n, Talca, Chile
}

infection and the third of bacteremia (Biendenbach et al. 2004). In Europe these infections are less and represent a 7.2\% of the total Martínez-Odrizola et al. (2007).

Enterococcal strains resistant to different antibiotics are a great public health problem, especially in isolated strains from hospital-acquired infections (Hidron et al. 2008). Several genetic studies have described the complex functions related to horizontal gene transfer in enterococcal strains, which partly explains their high antimicrobial resistance (Arthur et al. 1993; Clewell et al. 1995). Vancomycin was the antimicrobial agent most active against this bacterium, however, today in different parts of the world, isolated enterococcal strains are resistant to vancomycin (Ridwan et al. 2002; Chang et al. 2010).

Various factors determine the E. faecalis virulence, outstanding among those on the cellular surface, as the aggregation substance (Agg), the extracellular surface protein (Esp) and some that are excreted out of the bacterial cell as cytolysin and hyaluronidase, among others (Fisher and Phillips 2009; Semedo et al. 2003; Koch et al. 2004). Additionally, the Enterococcus spp. synthesizes heterogeneous antibacterial peptides or bacteriocins, also called enterocins (Giraffa 1995). These 
products may give these bacteria an additional ecological tool to persist in environments colonized by competing microorganisms in order to remove them and take over the ecological niche (Padilla et al. 2006).

In recent years, $E$. faecalis has a greater ability to cause infections on different human epithelia (Fisher and Phillips 2009). Thus, more studies are needed to provide new knowledge about this bacterial specie

Currently, there is considerable information regarding the antimicrobial susceptibility, presence of virulence genes and bacteriocins in E. faecalis strains isolated from clinical specimens and food. However, it would also be important to study if strains that come from water wells possess the properties mentioned and if it is possible to transmit these characteristics to the intestinal microbiota of people who drink this water.

Is important to remark that in some rural areas of central Chile, where there is no drinking water, people use well water for drinking and for various domestic purposes.
For a better understanding of the biology of E. faecalis, the objectives of this study were to detect genes for virulence and bacteriocins in addition to studying the antimicrobial susceptibility of 78 strains of E. faecalis isolated from water wells for human consumption.

\section{Materials and methods}

\section{Isolates and bacterial identification}

Were studied 128 water wells. In 78 of them were isolated 78 E. faecalis strains in the Maule Region in central Chile during the year 2010. From each well were taken $20 \mathrm{ml}$ of water with a sterile bottle at a deep of about $5 \mathrm{~cm}$. The samples were taken within $2 \mathrm{~h}$ to the microbiology laboratory of the University of Talca where they were processed immediately. The water samples were diluted 1:9 in sterile distilled water and $50 \mu \mathrm{l}$ of this dilution was plated on Bile-esculin agar (Merck, Darmstadt, Germany) and incubated at $37^{\circ} \mathrm{C}$ for $24 \mathrm{~h}$. The identification of the 78 bacterial isolates

Table 1 Oligonucleotide sequences used in this study and their products

\begin{tabular}{|c|c|c|c|}
\hline Virulence genes & Oligonucleotide sequences & Product size (bp) & Reference \\
\hline \multirow[t]{2}{*}{ CylA } & for5'-TGGATGATAGTGATAGGAAGT-3' & 517 & Eaton and Gasson 2001 \\
\hline & rev5'-TCTACAGTAAATCTITCGTCA-3' & & \\
\hline \multirow[t]{2}{*}{$\operatorname{agg} A$} & for5'-AAGAAAAAGTAGACCAAC-3' & 1553 & Eaton and Gasson 2001 \\
\hline & rev5'-AACGGCAAGACAAGTAAATA-3' & & \\
\hline \multirow[t]{2}{*}{ efaA } & for5'-GACAGACCCTCACGAATA-3' & 705 & Eaton and Gasson 2001 \\
\hline & rev5'-AGTTCATCATGCTGCTGTAGTA-3' & & \\
\hline \multirow[t]{2}{*}{ eep } & for5'-GAGCGGGTATTTTAGTTCGT-3' & 937 & Bittencourt de Marques and Suzart 2004 \\
\hline & rev5'-TACTCCAGCATTGGATGCT-3' & & \\
\hline \multirow[t]{2}{*}{ enlA } & for5'-TTCTTCTTATTCTGTCAACGCAGC-3' & 960 & Bittencourt de Marques and Suzart 2004 \\
\hline & rev5'-GACTGTGAAATACCTATTTGCAAGC-3' & & \\
\hline \multirow[t]{2}{*}{ esp } & for5'-TTGCTAATGCTAGTCCACGACC-3' & 933 & Shankar et al. 1999 \\
\hline & rev5'-GCGTCAACACTTGCATTGCCGAA-3' & & \\
\hline \multicolumn{4}{|l|}{ Bacteriocin genes } \\
\hline \multirow[t]{2}{*}{ as-48 } & for5'-GAGGAGGAGTATCATGGTTAAAG-3' & 340 & Sabia et al. 2008 \\
\hline & rev5'-CATATTGTTAAATTACCAAGCAATAA-3' & & \\
\hline \multirow[t]{2}{*}{ bac31 } & for5'-GAAAAAGAAATTAGTTATTTGTG-3' & 202 & Sabia et al. 2008 \\
\hline & rev5'-CTATCTAGGAGCCCAAGG-3 & & \\
\hline \multirow[t]{2}{*}{ entA } & for5'-ATGAAACATTTAAAAATTTTGTCTA-3' & 130 & Sabia et al. 2008 \\
\hline & rev5'-TTAGCACTTCCCTGGAATTG-3' & & \\
\hline \multirow[t]{2}{*}{ entB } & for5'-GAAAATGATCACAGAATGCCTA-3' & 160 & Du Toit et al. 2000 \\
\hline & rev5'-GTTGCATTAAGAGTATACATTTG-3' & & \\
\hline \multirow[t]{2}{*}{ entP } & for5'-GTTAGTTTGTGACAAATTTTGG-3' & 120 & Sabia et al. 2008 \\
\hline & rev5'-GGTGTGGAAAAGCCGTTTC-3' & & \\
\hline \multirow[t]{2}{*}{ entL50 A/B } & for5'-TGGGAGAATCGCAAAATTAG-3' & 96 & Du Toit et al. 2000 \\
\hline & rev5'-ATTGCCCATCCTTCTCCAAT-3' & & \\
\hline \multirow[t]{2}{*}{ ent1071 } & for5'-ATATTTAGGGGGACCGATAA-3' & 405 & Sabia et al. 2008 \\
\hline & rev5'-TATACATTCTTCCACTTATTIT--3' & & \\
\hline
\end{tabular}


Table 2 Virulence and bacteriocin genes in $\mathbf{7 8}$ Enterococcus faecalis strains isolated from water wells for human consumption

\begin{tabular}{|c|c|c|}
\hline Virulence genes & No & $\%$ \\
\hline $\operatorname{aggA}$ & 73 & 93.5 \\
\hline CylA & 60 & 76.9 \\
\hline efaA & 37 & 47.4 \\
\hline eep & 31 & 39.7 \\
\hline esp & 55 & 70.5 \\
\hline gele & 24 & 30.7 \\
\hline \multicolumn{3}{|l|}{ Bacteriocin genes } \\
\hline entB & 13 & 16.6 \\
\hline ent 1071 & 8 & 10.2 \\
\hline ent $P$ & 7 & 8.9 \\
\hline ent $L 50 A / B$ & 29 & 37.5 \\
\hline enlA & 21 & 26.9 \\
\hline entA & 50 & 64.1 \\
\hline bac31 & 11 & 14.1 \\
\hline as -48 & 0 & 0 \\
\hline
\end{tabular}

was carried out through conventional biochemical tests (Facklam and Collins 1989).

\section{Antibacterial susceptibility and determination of the minimum inhibitory concentration (MIC)}

The antibacterial susceptibility test was performed through the diffusion in agar test (Bauer et al. 1996). The antimicrobials analyzed were: ampicillin, tetracycline, ciprofloxacin, moxifloxacin, gentamicin, vancomycin, chloramphenicol y erythromycin (VALTEK, Santiago, Chile). For determination of MIC, the antimicrobial were prepared in accordance with the manufacturers' instructions (Sigma, St Louis, MO, USA) and in accordance with the recommended by EUCAST (2012). All the resolutions of the MICs were performed in duplicate. E. faecalis strain ATCC 29212 was included as control in assays with or without antimicrobials.

\section{Genes amplification and conditions for the PCR}

The total DNA of E. faecalis strains was used in the PCR reactions to detect the presence of virulence genes as cytolysin (cylA), aggregation substance (aggA), antigen A (efaA), stimulating of pheromones expression (eep), gelatinase $(g e l E)$ and surface protein $(e s p)$. Additionally were amplified the genes for enterocins AS-48 (as-48), bacteriocin 31 (bac31), enterocins A, B and P (entA, entB, entP), enterocin L50 A/B (entL50A/B), enterolysin A (enlA) and enterocin 1071 (ent1071). Each PCR reaction contained $10 \mathrm{mM}$ Tris- $\mathrm{HCl}$ buffer $\mathrm{pH} 8.3,1.5 \mathrm{mM} \mathrm{MgCl}$, $50 \mathrm{mM}$ $\mathrm{KCl}, 200 \mu \mathrm{M}$ of each deoxinucleotide (Omega, BioTek, Doraville, GA), $1 \mu \mathrm{M}$ of oligonucleotide, $2 \mathrm{U}$ of Taq DNA polymerase and $15 \mathrm{ng}$ of DNA template (Table 1).
The reactions conditions for each gene were the following:

For the amplification of the virulence genes cylA, aggA, $e f a A$, eep, gelE and esp, the samples with the DNA templates were denatured at $94^{\circ} \mathrm{C}$ by $5 \mathrm{~m}$. Subsequently, 30 cycles were performed: $45 \mathrm{~s}$ at $94^{\circ} \mathrm{C}, 1 \mathrm{~m}$ at $57^{\circ} \mathrm{C}$ and $1 \mathrm{~m}$ at $72^{\circ} \mathrm{C}$ for the gene cylA; 30 cycles of $45 \mathrm{~s}$ at $94^{\circ} \mathrm{C}, 1 \mathrm{~m}$ at $52^{\circ} \mathrm{C}$ and $1 \mathrm{~m}$ at $72^{\circ} \mathrm{C}$ for the aggA and efaA genes; 30 cycles of $45 \mathrm{~s}$ a $94^{\circ} \mathrm{C}, 1 \mathrm{~m}$ at $58^{\circ} \mathrm{C}$ and $1 \mathrm{~m}$ at $72^{\circ} \mathrm{C}$ for the eep gene; 30 cycles of $30 \mathrm{~s}$ at $94^{\circ} \mathrm{C}, 30 \mathrm{~s}$ at $56^{\circ} \mathrm{C}$ and $30 \mathrm{~s} 72^{\circ} \mathrm{C}$ for the gelE gene; 30 cycles of $45 \mathrm{~s}$ at $94^{\circ} \mathrm{C}$, $1 \mathrm{~m}$ at $62^{\circ} \mathrm{C}$ and $1 \mathrm{~m}$ at $72^{\circ} \mathrm{C}$ for the esp gene. The amplification of all the virulence genes was concluded with a final extension of $72^{\circ} \mathrm{C}$ by $3 \mathrm{~m}$.

The PCR were performed in a thermal DNA Engine (Bio-Rad, Hercules, CA). The negative controls (without DNA template) were included in each reaction set and all performed double. The amplification products were analyzed through electrophoresis in agarose gels at 1.5\% stained with ethidium bromide and visualized under ultraviolet light. The size of each amplified product was confirmed by comparison with the molecular size marker $1 \mathrm{~Kb}$-Plus DNA ladder (New England Biolabs).

\section{Statistical analysis}

The correlation between the presence of virulence and bacteriocin genes with the antimicrobial susceptibility of the E. faecalis strains, was determined using the Test of $\mathrm{X}^{2}$ of Test Exact of Fisher, as it corresponded. A p $<0.05$ value was considered statistically significant to indicate the association between both variables. The statistical package used was SPSS v.19.0.

\section{Results}

From 128 water wells were isoalted 78 E. faecalis strains and were identified by conventional biochemical test.

Table 3 Virulence and bacteriocin genetic profiles in $78 \mathrm{E}$. faecalis strains isolated from water wells for human consumption

\begin{tabular}{llll}
\hline Genetic profiles & & \multicolumn{2}{l}{ Strains } \\
\hline Virulence genes & Bacteriocins & $\mathbf{n}^{\mathbf{0}}$ & $\mathbf{\%}$ \\
\hline (A) * efaA, aggA, esp, gelE, cylA, eep & entA, bac31 & 11 & 14.1 \\
\hline (B) efaA, aggA, esp, gelE, cylA & entA, entB & 8 & 10.2 \\
\hline (C) efaA, aggA, esp, gelE & entA, entL50A/B & 18 & 23.0 \\
\hline (D) aggA, esp, cylA, eep & enIA, entP & 7 & 8.9 \\
\hline (E) aggA, esp, cylA & entL50A/B, enIA & 11 & 14.1 \\
\hline (F) cylA, gelE, eep & entA, entB & 5 & 6.4 \\
\hline (G) cylA, eep, aggA & entA, ent 1071 & 8 & 10.4 \\
\hline (H) cylA, aggA, gelE & entA, enlA & 10 & 12.8 \\
\hline & & 78 & 100 \\
\hline
\end{tabular}

*: Name of genetic profile. 
Table 4 MICs of several antimicrobials against different resistance phenotypes of $E$. faecalis isolated from wells of water for human consumption

\begin{tabular}{|c|c|c|c|c|c|c|c|c|c|}
\hline \multicolumn{10}{|c|}{ Median MIC (range) (mg/L) } \\
\hline Resistance phenotype & Numbers of strains & $\mathbf{T}$ & A & $\mathbf{V}$ & $\mathrm{C}$ & M & $\mathrm{Ch}$ & $\mathbf{G}$ & $\mathrm{E}$ \\
\hline $\mathrm{TACh} G$ & 8 & $64(16-256)$ & $16(4-128)$ & & & & $64(32-256)$ & $16(8-128)$ & \\
\hline GACh E & 10 & & $16(8-64)$ & & & & $64(32-128)$ & $32(16-64)$ & $16(8-64)$ \\
\hline TACh E & 7 & $32(8-128)$ & $8(8-64)$ & & & & $16(8-128)$ & & $16(8-64)$ \\
\hline $\mathrm{TGA}$ & 11 & $64(16-128)$ & $8(8-64)$ & & & & & $32(16-128)$ & \\
\hline $\mathrm{TCh}$ & 14 & $64(16-256)$ & & & & & $64(32-256)$ & & \\
\hline$\overline{A G}$ & 6 & & $16(8-128)$ & & & & & $32(16-256)$ & \\
\hline $\mathrm{TC}$ & 4 & $32(8-128)$ & & & $8(4-32)$ & & & & \\
\hline$\overline{C M}$ & 2 & & & & $8(4-32)$ & $16(32-128)$ & & & \\
\hline $\mathrm{Ch}$ & 5 & & & & & & $64(32-256)$ & & \\
\hline$T$ & 6 & $64(16-128)$ & & & & & & & \\
\hline $\bar{G}$ & 5 & & & & & & & $32(16-256)$ & \\
\hline Total & 78 & & & & & & & & \\
\hline
\end{tabular}

\section{Virulence and bacteriocin PCR products}

In the Table 2 it was observed that the entA gene $(64.1 \%)$ is the most frequently detected followed by the entL50A/B (37.5\%) and the enlA $(26.9 \%)$ gene respectively. The ent $P(8.9 \%)$ gene was the less frequent. The gene as-48 was not detected. In the Table 3 , it is observed that 11 of the total of the studied strains exhibit 6 virulence genes and 2 bacteriocin genes. The main genetic profile was observed in $18 \mathrm{E}$. faecalis strains, in which 4 different virulence genes and 2 bacteriocinogenic genes were detected. The less common profile corresponded to 5 strains that carried 3 virulence genes and 2 bacteriocinogenic genes. Eight genetic profiles were determined that include virulence and bacteriocin genes (A, B, C, D, E, F, G y H profiles).

\section{Antimicrobial susceptibility}

The Table 4 shows the resistance phenotypes (MICs) of the $78 \mathrm{E}$. faecalis strains. It is observed that 3 phenotypes exhibit resistance to 4 antibiotics simultaneously and 3 phenotypes show resistance to only one. In the same table, it is observed that the most common resistance phenotype $(\mathrm{n}=14)$ corresponds to a tetracycline and chloramphenicol and the less frequent $(n=2)$ to ciprofloxacin and moxifloxacin. It was not observed resistance to vancomycin in any of the strains evaluated.

\section{Relation between antimicrobial susceptibility and genetic} profiles

In accordance to statistical analysis it was observed a significant association between the resistance to tetracycline and chloramphenicol with the genetic profiles $\mathrm{A}$, $\mathrm{B}, \mathrm{C}, \mathrm{D}$ and $\mathrm{F}$ and of sensitivity in presence of the genetic profiles $\mathrm{E}$ and $\mathrm{H}$. It was observed that ampicillin resistance is associated to the genetic profiles $\mathrm{A}, \mathrm{B}, \mathrm{C}$ y D and of sensitivity with $E$ and $F(p<0.0001)$. The genetic profiles associated with the resistance to gentamicin were A, B, D and F and of sensitivity C and $\mathrm{E}(\mathrm{p}<0.0001)$.

Table 5 Relation of virulence and bacteriocin genetic profiles and their respective antimicrobial resistance in E. faecalis strains isolated from water wells for human consumption

\begin{tabular}{|c|c|c|c|c|c|c|c|c|c|}
\hline \multirow[t]{2}{*}{ Virulence and bacteriocin } & & \multicolumn{8}{|c|}{ № of resistant strains and antimicrobials genetic profiles } \\
\hline & & $\mathbf{T}$ & A & V & C & M & $\mathrm{Ch}$ & G & $\mathrm{E}$ \\
\hline efaA, aggA, esp, gelE, cylA, eep & entA, bac31 & 11 & 9 & 0 & 2 & 1 & 11 & 8 & 3 \\
\hline efaA, aggA, esp, gelE, cylA & ent $A$, ent $B$ & 6 & 8 & 0 & 1 & 0 & 8 & 8 & 4 \\
\hline efaA, aggA, esp, gelE & ent $A$, ent $L 50 A B B$ & 12 & 11 & 0 & 1 & 1 & 11 & 3 & 3 \\
\hline aggA, esp, cylA, eep & enIA, entP & 5 & 4 & 0 & 0 & 0 & 5 & 7 & 2 \\
\hline aggA, esp, cylA & ent $L 50 A / B$, enIA & 3 & 3 & 0 & 0 & 0 & 0 & 4 & 1 \\
\hline cylA, gelE, eep & ent $A$, ent $B$ & 3 & 1 & 0 & 0 & 0 & 3 & 4 & 1 \\
\hline cylA, eep, aggA & ent $A$, ent 1071 & 4 & 2 & 0 & 0 & 0 & 4 & 2 & 0 \\
\hline cylA, aggA, gelE & ent $A$, enlA & 5 & 2 & 0 & 0 & 0 & 2 & 3 & 3 \\
\hline Total & & 49 & 40 & 0 & 4 & 2 & 44 & 39 & 17 \\
\hline
\end{tabular}

T: tetracycline; A: ampicillin; V: vancomycin ; C: ciprofloxacin; M: moxifloxacin; Ch: chloramphenicol; G: gentamicin; E: erythromicin. 
Erythromicin, ciprofloxacin, moxifloxacin and vancomycin did not exhibit a significant statistically susceptibility association with the genetic profiles detected.

In the Table 5, it is observed that the E. faecalis strains that exhibit a greater number of virulence and bacteriocin genes were more resistant to the antimicrobial. The greatest number of resistant strains was associated with tetracycline followed by chloramphenicol, ampicillin and gentamicin respectively. The lowest resistance of the strains was observed for moxifloxacin and ciprofloxacin.

\section{Discussion}

Enterococcus faecalis is a very important bacterial specie as a pathogen acquired in hospitals of USA and Europe, especially in intensive care units, where are one of the main causes of bacteremia (Rodríguez-Baño et al. 2005). Although there are various surveys addressed to know the causes because these microorganisms induce human infections, diverse aspects of its biology have not been revealed (Fisher and Phillips 2009).

The results demonstrated that the majority of the bacterial strains had genes that codify for different virulence factors. The results of this study are coherent with the described in other studies (Koch et al. 2004; Dupont et al. 2008). The enterocin genes analyzed in this work represent the most frequently described in this bacterial specie (Franz et al. 2007). The bateriocinogenic activity of E. faecalis is widely recognized and its bacteriocins have been object of interesting biotechnological studies associated to the biopreservation of foods (Khan et al. 2010; Poeta et al. 2007). The bacteriocinogenic capacity of these microorganisms grants an ecological superiority with respect to those strains that do not produce these antibacterial peptides. This property also grants survival advantages to the bacteriocinogenic strains, because these products are able to eliminate to potential competing microorganisms and start subsequently the colonization phase. It was very interesting to observe that all the studied strains exhibited two different types of genes for bacteriocins, which added to its respective virulence genes grant to these strains a greater pathogenic potentiality. Thus, bacteriocinogenic strains have an additional ecological tool to persist in environments colonized by competing microorganisms. Probably once introduced in the organism with the water these strains can more easily colonize; on the contrary they do not have an ecological benefit in aquatic environment where virulence factors and bacteriocins are diluted.

It was shown in this finding that most of the strains exhibit resistance to two or more antimicrobials. Specifically 25 strains present resistance to four different types of the antimicrobials used. This important resistance associated to high MICs confirms the recognized antimicrobial property of $E$. faecalis which is maintained in the studied strains. Also, in accordance to statistical analysis it is possible to argue that genetic profiles A, B, and D of E. faecalis are more frequently associated to resistance against some antimicrobials and inversely, the profiles $C$ and $E$ are associated with sensitivity.

The evolution and ecology of $E$. faecalis, is a subject of great importance and that must be constantly monitored to have new information to allow to know the biology of this bacterial specie. The results of this study demonstrate that intensive use of water wells for human consumption includes poor sanitary practices. This is the cause of bacterial contamination of the wells with human microbiota. This could explain the presence of E. faecalis in these wells. Although, generally contamination of the wells is due to environmental contamination of groundwater by fecal pollution, it is possible to consider that E. faecalis strains analyzed are circulating among the wells and the people who use this water resource. The observed properties in the studied bacterial strains are similar to those found in strains isolated from clinical samples. On the other hand, these strains are a serious problem for people who drink this water contaminated with $E$. faecalis, considering that these bacteria could transfer genetic information from antimicrobial resistance to their intestinal microbiota (De Niederhäusern et al. 2011).

\section{Competing interest}

The authors declare that they have no competing interest.

\section{Authors' contributions}

CP: carried out part of the bacterial identification; carried out part of the molecular genetic studies; to made part of the writing and design of the manuscript; carried out the statistical analysis OL: carried out part of the bacterial identification; carried out part of the molecular genetic studies; to made part of the writing and design of the manuscript; carried out the statistical analysis The authors declare: All authors read and approved the final manuscript.

Received: 22 November 2012 Accepted: 31 January 2013

Published: 9 February 2013

\section{References}

Arthur M, Molina C, Depardieu F, Courvalin P (1993) Characterization of TN1546, a Tn3 - related transposon conferring glycopeptide resistance by synthesis of depsipeptide peptidoglycan precursors in Enterococcus faecium BM4147. J Bacteriol 175:117-127

Bauer A, Kirby M, Sherris J, Turck M (1996) Antibiotic susceptibility testing by a standardized single disk method. Amer J Clin Pathol 45:493-496

Biendenbach DJ, Moet GJ, Jones RN (2004) Occurrence and antimicrobial resistance pattern comparisons among bloodstream infection isolates from the SENTRY antimicrobial surveillance program. Diag Micr Infec Dis 50:59-69

Bittencourt de Marques E, Suzart S (2004) Occurrence of virulence- associated genes in clinical Enterococcus faecalis strains isolated in Londrina, Brazil. J Med Microbiol 53:1069-1073

Chang CM, Wang LR, Lee HC, Lee NY, Wu CJ, Ko WC (2010) Characterization of vancomycin-resistant enterococci from hospitalized patients at a tertiary center over a seven-year period. J Hosp Infect 74:377-384

Clewell DB, Flannagan SE, Jaworski DD (1995) Unconstrained bacterial promiscuity: the Tn916-Tn1545 family of conjugative transposons. Trends Microbiol 3:229-236 
Cookson BD, Macrae MB, Barret SP, Brown DJ, Chadwick C, French GL, Hateley P, Hosein IK (2006) Guidelines for the control of glycopeptide-resistant enterococci in hospitals. J Hosp Infect 62:6-21

De Niederhäusern S, Bondi M, Messi P, Iseppi R, Sabia C, Manicardi G, Anacarso I (2011) Vancomycin-resistance transferability from VanA enterococci to Staphylococcus aureus. Curr Microbiol 62:1363-1367

Du Toit M, Franz CM, Dicks LM, Holzapfel WH (2000) Preliminary characterization of bacteriocins produced by Enterococcus faecium and Enterococcus faecalis isolated from pig faeces. J Appl Microbiol 88:482-494

Dupont H, Vael C, Muller-Serieys C, Chosidow D, Marmuse J, Andremont A, Goossens H, Desmonts J (2008) Prospective evaluation of virulence factors of enterococci isolated from patients with peritonitis. Impact on outcome. Diag Microb Infect Dis 60:247-253

European Society of Clinical Microbiology and Infectious Diseases (2012) EUCAST disk diffusion method for antimicrobial susceptibility testing. Version 2.1 (February)

Facklam R, Collins M (1989) Identification of Enterococcus species isolated from human infections by a conventional test scheme. J Clin Microbiol 27:731-734

Fisher K, Phillips C (2009) The ecology, epidemiology and virulence of Enterococcus. Microbiology 155:1749-1757

Franz CM, Van Belkum MJ, Holzapfel WH, Abriouel H, Gonçalvez A (2007) Diversity of enterococcal bacteriocins and their grouping in a new classification scheme. FEMS Microbiol Rev 31:293-310

Giraffa G (1995) Enterococcal bacteriocins: their potential use as anti-Listeria factors in dairy technology. Food Microbiol 12:551-556

Hidron Al, Edwards JR, Patel J, Hora TC, Sievert DM, Pollock DA, Fridkin SA (2008) NHSN annual update: antimicrobial-resistant pathogenes associated with heathcare-associated infections: annual summary of data reported to the National Healthcare Safety Network at the Centers for Disease Control Prevention, 2006-2007. Infect Control Hosp Epidemiol 29:996-1011

Khan H, Flint S, Yu PL (2010) Enterocins in food preservation. Int J Food Microbiol 141:1-10

Koch S, Hufnagel M, Theilackers C, Huebner J (2004) Enterococcal infections host response therapeutic and prophylactic possibilities. Vaccine 22:822-830

Köhler W (2007) The present state of species within the genera Streptococcus and Enterococcus. IJMM 297:133-150

Martínez-Odrizola P, Muñoz-Sánchez P, Gutierrez-Macías A, Arriola-Martínez P, Montero-Aparicio E, Ezpeleta-Baquedano C (2007) Análisis de 182 episodios de bacteremia por enterococo: estudio de la epidemiología, microbiología y evolución clínica. Enferm Infecc Microbiol Clin 25:503-507

Naser S, Thompson FL, Hoste B, Gevers D, Vandmeulebroecke K, Cleenwerck I, Thompson C, Vancanneyt M (2005) Phylogeny and identification of enterococci by atpA genee sequence analysys. J Clin Microbiol 43:2224-2230

Padilla C, Lobos O, Brevis P, Abaca P, Hubert E (2006) Plasmid-mediated bacteriocin production by Shigella flexneri isolated from dysenteriae diarrhea and their transformation into Escherichia coli. Lett Appl Microbiol 42:300-303

Poeta P, Costa D, Rojo-Bezares B, Zarazaga M, Klibi N, Rodriguez J, Torres C (2007) Detection of antimicrobial activities and bacteriocin structural genes in faecal enterococci of wild animals. Microbiol Res 162:257-263

Poh CH, Oh HM, Tan AL (2006) Epidemiology and clinical outcome of enterococcal bacteraemia in an acute care hospital. J Infect 52:383-386

Ridwan B, Mascini E, Van Der Reijden N, Verhoef J, Bonten M (2002) What action should be taken to prevent spread of vancomycin resistant enterococci in European hospitals? BMJ 324:666-668

Rodríguez-Baño J, Ramírez E, Muniain M, Santos J, Joyanes P, González F, GarcíaSánchez M, Martínez-Martínes L (2005) Colonization by high-level aminoglycoside-resistant enterococci in intensive care unit patients. Epidemiology and clinical relevance. J Hosp Infect 60:353-359

Sabia C, Niederhaüsen S, Guerrieri E, Anacarso I, Manicardi G, Bondi M (2008) Detection of bacteriocin production and virulence traits in vancomicynresistant enterococci of different sources. J Appl Microbiol 104:970-979

Semedo T, Santos MA, Lopes MF, Marquez JJ, Crespo MT, Tenreiro R (2003) Virulence factors in food, clinical and reference enterococci: a common trait in the genes? Syst Appl Microbial 26:13-22

Shankar V, Baghdayan AS, Huycke MM, Lindahl G, Gilmore MS (1999) Infectionderived Enterococcus faecalis strains are enriched in esp, a gene encoding a novel surface protein. Infect Immun 67:193-200

Shepard BD, Gilmore MS (2000) Differential expression of virulence related genes in Enterocococcus faecalis in response to biological cues in serum and urine. Infect Immun 70:4344-4352
Treitman AN, Yarnols PR, Warren J, Noskin GA (2005) Emerging incidence of Enterococcus faecium among hospital isolates (1993 to 2002). J Clin Microbiol 43:462-463

Eaton TJ, Gasson MJ (2001) Molecular screening of Enterococcus virulence determinants and potential for genetic exchange between food and medical isolates. Appl Environ Microbiol 67:1628-1635

doi:10.1186/2193-1801-2-43

Cite this article as: Padilla and Lobos: Virulence, bacterocin genes and antibacterial susceptibility in Enterococcus faecalis strains isolated from water wells for human consumption. SpringerPlus 2013 2:43.

\section{Submit your manuscript to a SpringerOpen ${ }^{\circ}$ journal and benefit from:}

- Convenient online submission

Rigorous peer review

- Immediate publication on acceptance

- Open access: articles freely available online

- High visibility within the field

- Retaining the copyright to your article

Submit your next manuscript at $>$ springeropen.com 